\title{
PROSES PENJAMINAN MUTU LEMBAGA PENDIDIKAN ISLAM MELALUI MANAJEMEN MUTU TERPADU
}

\author{
M. Sobry ${ }^{*}$
}

\begin{abstract}
Abstrak: Mengingat pentingnya aspek pendidikan, maka harus diupayakan agar lembaga pendidikan islam bisa bermutu. Suatu hal yang mendesak untuk diupayakan adalah memperkuat manajemen lembaga pendidikan islam. Dalam hal ini manajemen mutu terpadu perlu diupayakan karena merupakan salah satu strategi manajemen untuk menjawab berbagai tantangan suatu lembaga guna untuk memenuhi kepuasan pelanggan melalui pencegahan serta mengurangi kesalahan dan resiko. Lembaga pendidikan islam harus mampu menjamin agar mutunya bisa dijaga dan ditingkatkan. Salah satu model penjaminan mutu yang bisa diterapkan adalah manajemen model PDCA (Plan, Do, Check, Action). Adapun implementasi PDCA sangat bermanfaat untuk melakukan perbaikan secara terus menerus tanpa berhenti.
\end{abstract}

Kata Kunci: Lembaga Pendidikan Islam, Mutu, Manajemen Mutu Terpadu, Penjaminan Mutu

Ketua Lembaga Penelitian dan Pengabdian Kepada Masyaratat (LP2M) IAIN Mataram 


\section{Pendahuluan}

etiap warga negara berhak memperoleh pendidikan secara - merata dengan keunggulan dan penyeimbangan antara Pemanfaatan dengan prestasi. Dalam hal ini pendidikan merupakan proses untuk mengintegrasikan individu yang sedang mengalami pertumbuhan di dalam masyarakat. Dalam kegiatan pendidikan terjadi pembinaan terhadap perkembangan berbagai potensi anak untuk memenuhi kelangsungan hidupnya secara pribadi serta kesejahteraan di masyarakat. Dalam UU Sisdiknas No 20/2003 pasal 3, bahwa tujuan pendidikan nasional berfungsi untuk mengembangkan kemampuan dan membentuk watak serta peradaban bangsa yang bermartabat dalam rangka mencerdaskan kehidupan bangsa, bertujuan untuk mengembangkan potensi peserta didik agar menjadi manusia yang beriman dan bertakwa kepada Tuhan Yang Maha Esa, berakhlak mulia, sehat, berilmu, cakap, kreatif, mandiri, menjadi warga yang demokratis, serta bertanggung jawab (Dedi Hamid, 2003). Undang-undang tersebut menunjukkan bahwa pendidikan ditujukan untuk menyiapkan manusia untuk menghadapi masa depan agar hidup lebih sejahtera, baik sebagai individu maupun sebagai makhluk sosial. Di sini menunjukkan bahwa mutu pendidikan adalah faktor kunci dalam kompetisi di era globalisasi. Mutu produk dan pelayanan yang dihasilkan berbagai lembaga pendidikan islam sangat ditentukan oleh kemampuan manajerial, kepemimpinan, visi, dan integritas kepribadian para manajer, guru-guru, maupun pegawai dalam memanaj pendidikan. Dalam hal ini Sallis (2012), mengatakan bahwa bagi setiap institusi, mutu adalah agenda utama dan meningkatkan mutu merupakan tugas yang paling penting.

Kaitan soal mutu, dewasa ini perkembangan pemikiran manajemen pendidikan mengarah pada sistem manajemen yang disebut Total Quality Management atau Manajemen Mutu Terpadu. Pada prinsipnya sistem manajemen ini adalah pengawasan menyeluruh dari lembaga/organisasi pendidikan termasuk lembaga pendidikan islam terhadap kegiatan pendidikan. Penerapan manajemen mutu terpadu berarti semua warga lembaga pendidikan 
bertanggung jawab atas kualitas pendidikan. Sebelum hal itu tercapai, maka semua pihak yang terlibat dalam kegiatan akademis, mulai dari pimpinan lembaga pendidikan, kepala tata usaha, guru/dosen, siswa/mahasiswa sampai dengan karyawan/staf/ pegawai harus betul-betul mengerti hakekat dan tujuan pendidikan. Dengan kata lain, setiap individu yang terlibat harus memahami apa tujuan penyelenggaraan pendidikan. Tanpa pemahaman yang menyeluruh dari individu yang terlibat, tidak mungkin akan diterapkan manajemen mutu terpadu. Lulusan bermutu merupakan sumber daya manusia yang kita harapkan bersumber dari lembaga pendidikan yang bermutu. Dalam teori mobilisasi sumber daya, kekuatan masyarakat untuk melakukan perubahan tergantung kepada seberapa kuat adanya perubahan yang akan dilakukan oleh masyarakat menuju perubahan yang lebih baik ke depannya (Robert Mirsel (2004). Oleh karenanya, jika dihubungkan dengan aspek pendidikan, maka mutu pendidikan yang akan diraih tergantung dari seberapa besar upaya yang dilakukan untuk mewujudkannya.

\section{Lembaga Pendidikan Islam}

Lembaga pendidikan islam secara terminologi dapat diartikan sebagai suatu wadah atau tempat berlangsungnya proses pendidikan islam (Abu Ahmadi dan Nur Uhbiyati, dalam Ramayulis, 2002). Defenisi tersebut menunjukkan bahwa lembaga pendidikan tersebut mengandung pengertian bentuk dan juga pengertianpengertian yang abstrak, adanya norma-norma tertentu serta yang bertanggung jawab terhadap lembaga pendidikan itu sendiri. Menurut Ramayulis (2002) bahwa lembaga pendidikan islam merupakan hasil pemikiran yang dicetuskan oleh kebutuhankebutuhan masyarakat yang didasari, digerakkan, dan dikembangkan oleh jiwa islam (al-qur'an dan al-sunnah). Menurut Mujamil Qomar (2007), upaya manajemen maupun pengembangan lembaga pendidikan islam merupakan keniscayaan dan beban kolektif bagi para penentu kebijakan pendidikan islam. Mereka memiliki kewajiban untuk merumuskan strategi dan mempraktikkannya guna memajukan pendidikan Islam. 
Di era globalisasi seperti saat ini, upaya-upaya untuk meningkatkan mutu lembaga pendidikan islam merupakan hal yang teramat penting untuk bisa diwujudkan. lembaga pendidikan islam harus tetap memperhatikan aspek mutu.

\section{Konsep Mutu}

Menurut Nana Syaodih Sukmadinata, Ayi Novi Jami'at dan Ahman (2003) bahwa program mutu sebenarnya berasal dari dunia bisnis. Dalam dunia bisnis, baik yang bersifat produksi maupun jasa, mutu merupakan program utama, sebab kelanggengan dan kemajuan usaha sangat ditentukan oleh mutu sesuai dengan permintaan dan tuntutan pengguna. Mutu memiliki makna yang bermacam-macam tergantung orang yang memaknainya atau tergantung dari sisi mana orang memandang. Mutu, secara umum diartikan sebagai keseluruhan gambaran dan karakteristik suatu produk berkaitan dengan pemenuhan kebutuhan konsumen. Mutu menurut Deming ialah kesesuaian dengan kebutuhan. Sallis (2003) mengemukakan bahwa mutu adalah konsep yang absolut dan relatif. Mutu yang absolut adalah mutu yang mempunyai idealisme tinggi dan berstandar tinggi yang harus dipenuhi, dengan sifat produk bergengsi yang tinggi. Sedangkan mutu relatif adalah sebuah alat yang sudah ditetapkan dan harus memenuhi standar yang telah dibuat. Adapun Istilah mutu menurut Juran (dalam Arcaro, 2005) adalah "tepat untuk dipakai" dan menegaskan bahwa dasar misi mutu sebuah sekolah (lembaga pendidikan) adalah "mengembangkan program dan layanan yang memenuhi kebutuhan pengguna seperti siswa dan masyarakat". Lebih lanjut Juran mengatakan bahwa "tepat untuk dipakai lebih tepat ditentukan oleh pemakai bukan oleh pemberi. Beberapa pandangan Juran (dalam Arcaro, 2005) tentang mutu, yaitu: (1) Meraih mutu merupakan proses yang tidak mengenal akhir; (2) Perbaikan mutu merupakan proses berkesinambungan, bukan proses sekali jalan; (3) Mutu memerlukan kepemimpinan dari anggota dewan sekolah dan administrator; (4) Pelatihan massal merupakan persyaratan mutu; (5) Setiap orang di sekolah mesti mendapatkan pelatihan. 
Nanang Fattah (2013) mengartikan mutu sebagai kemampuan yang dimiliki oleh suatu produk atau jasa yang dapat memenuhi kebutuhan atau harapan, kepuasan pelanggan yang dalam pendidikan dikelompokkan menjadi dua yaitu internal customer dan eksternal. Dalam konteks pendidikin, mutu mengacu pada proses pendidikan dan hasil pendidikan. Dalam proses pendidikan yang bermutu, terlibat berbagai input, seperti: materi pembelajaran, metodologi menyampaikan materi pada saat proses pembelajaran, media pembelajaran, dukungan administrasi dan sarana prasarana dan sumber daya lainnya; Mutu dalam konteks hasil pendidikan mengacu pada prestasi yang dicapai oleh lembaga pendidikan pada setiap kurun waktu tertentu. Pendidikan dikatakan bermutu apabila semua input dan proses sesuai dengan standar mutu yang diterapkan.

Nana Syaodih Sukmadinata, Jami'at dan Ahman (2006) menjelaskan bahwa mutu pendidikan bersifat menyeluruh, menyangkut semua komponen, pelaksana, dan kegiatan pendidikan, atau disebut sebagai mutu total atau "Total Quality". Adalah sesuatu yang tidak mungkin hasil pendidikan yang bermutu dapat dicapai hanya dengan satu komponen atau kegiatan yang bermutu. Tujuan mutu adalah terfokus pada pemenuhan kebutuhan pelanggan, mendorong keterlibatan total komunitas dalam program, mengembangkan sistem pengukuran nilai tambah pendidikan, menunjang sistem yang diperlukan staf dan siswa untuk mengelola perubahan, serta perbaikan terus menerus dengan selalu berupaya sekuat tenaga untuk membuat produk pendidikan menjadi lebih baik. Menurut Sobry Sutikno (2007), bahwa tujuan akhir dari pendidikan bemutu ialah untuk mencapai kepuasan pelanggan atau bersesuaian dengan harapan masyarakat. Agar pendidikan dapat berjalan dengan sebaik-baiknya, program studi atau jurusan yang tersedia harus bersesuaian dengan harapan masyarakat dan selaras dengan tuntutan zaman. Para pimpinan lembaga pendidikan islam harus mengoptimalkan mutu pendidikan untuk memenuhi harapan pelanggan. Dengan adanya kerjasama antara berbagai komponen dalam suatu sistem pendidikan, baik itu tujuan pendidikan, faktor 
pendidik, peserta didik, kurikulum, metode pendidikan, lembaga pendidikan akan dapat mencapai mutu pendidikan sesuai dengan yang dicita-citakan. Sallis (2012) menjelaskan bahwa tujuan analisis mutu adalah lebih tepat digunakan untuk melihat pendidikan sebagai sebuah industri jasa dari pada sebagai sebuah proses produksi. Pandangn semacam ini sangat dibutuhkan institusi untuk mendefinisikan jasa dan standar yang akan mereka berikan.

\section{Manajemen Mutu Terpadu dalam Pendidikan}

Manajemen Mutu Terpadu diterjemahkan dari Total Quality Management adalah suatu pendekatan mutu pendidikan melalui peningkatan mutu komponen terkait. Menurut Harianto (2005), manajemen mutu terpadu merupakan sebuah konsep yang meliputi usaha meningkatkan mutu secara terus menerus pada semua tingkatan manajemen dan seluruh struktur yang terdapat dalam organisasi. Manajemen mutu terpadu menurut (Fandy Tjiptono dan Anastasia Diana, 1995) merupakan sistem manajemen yang mengangkat kualitas sebagai strategi usaha dan berorientaasi pada kepuasan pelanggan dengan melibatkan seluruh anggota organisasi. Sallis (2003) berpendapat bahwa manajemen mutu terpadu berarti menjamin mutu dan standar dalam pendidikan. Mutu terpadu memandang pendidikan sebagai sebuah sistem total, yang dibentuk sejumlah komponen internal dan eksternal. Hanya dengan memperbaiki keseluruhan sistem pendidikan maka para profesional pendidikan dapat membuat perbaikan mutu seperti yang diminta masyarakat. Mutu dalam pendidikan meminta adanya komitmen pada kepuasan kostumer dan komitmen untuk menciptakan sebuah lingkungan yang memungkinkan para staf dan siswa menjalankan pekerjaan sebaik-baiknya. Manajemen mutu terpadu ini dapat disebut sebagai suatu perangkat, yang mana sistem manajemen dapat mengarahkan pencapaian tujuan organisasi secara efektif dan efisien, untuk menjamin kepuasan pelanggan dan memaksimalkan nilai pemangku kepentingan.

Menurut Furqon dan Tola (2002) mutu pendidikan di sekolah (lembaga pendidikan) merupakan fungsi dari mutu input peserta 
didik yang ditunjukkan oleh potensi peserta didik, mutu pengalaman belajar yang ditunjukkan oleh kemampuan profesional guru, mutu penggunaan fasilitas belajar, dan budaya sekolah yang merupakan refleksi mutu kepemimpinan kepala sekolah. Upaya peningkatan kualitas pendidikan pada sekolah perlu terus menerus diupayakan.

Menurut Joseph C.Field (dalam Syafaruddin, 2002), mutu terpadu pendidikan adalah setiap orang bertanggung jawab atau berkewajiban untuk mencapai atau mengejar kepuasan pelanggan. Suatu mutu terpadu dalam pendidikan membuat setiap orang berjanji untuk melayani orang lain berdasarkan setiap tuntutan kebutuhan pendidikan. Di sisi lain, Pupuh Fathurrohman dan AA Suryana (2011) menjelaskan manajemen mutu terpadu merupakan pendekatan yang komprehensif dan integratif merupakan cara organisasi dalam memenuhi kebutuhan konsumen secara konsisten mencapai perkembangan pembaharuan secara kontinyu dalam setiap aspek aktivitas organisasi. Konsumen haruslah diberikan pelayanan terbaik, karena merekalah organisasi tumbuh dan berkembang. Selanjutnya, Pupuh Fathurrohman dan AA Suryana menjelaskan bahwa tujuan manajemen mutu terpadu adalah memberikan kepuasan terhadap kebutuhan pelanggan seefisien mungkin, bahkan manajemen mutu terpadu dalam pendidikan dapat menguntungkan semua pihak dengan asumsi bahwa manajer pedidikan dapat mengelaola lembaga pendidikan tersebut untuk senantiasa berorientasi pada perbaikan mutu yang terus menerus sejalan dengan perkembangan internal dan eksternal organisasi serta bersifat transparan bisa diaudit hasil dan prosesnya. Serta akan dilakukan evaluasi setelah proses dilaksanakan. Dalam manajemen mutu terpadu, mutu ditentukan oleh para pelanggan baik pelanggan internal maupun eksternal. Oleh karena itu hanya dengan memahami proses dan pelanggan maka lembaga pendidikan dapat menyadari dan menghargai makna mutu. Semua upaya dalam manajemen mutu terpadu harus selalu diarahkan pada tujuan utama, yaitu tercapainya kepuasan pelanggan. 
Menurut Joseph C.Field, ada tujuh prinsip manajemen mutu terpadu dalam pendidikan, yaitu: (1) komitmen manajemen terpadu, (2) selalu mengutamakan pelanggan, (3) komitmen terhadap tim kerjasama, (4) komitmen terhadap manajemen pribadi dan kepemimpinan, (5) komitmen terhadap perbaikan terus menerus, (6) komitmen terhadap kepercayaan kemampuan pribadi dan tim, (6) komitmen untuk meraih mutu. Berkaitan dengan manajemen mutu terpadu, Arcaro (2005) menjelaskan ada lima pilar yang perlu dipahami sebelum mengembangkan lembaga pendidikan/sekolah bermutu total, yaitu: (1) focus pada kostumer, (2) keterlibatan total, (3) pengukuran, (4) komitmen, (5) perbaikan berkelanjutan. Fokus pada Kostumer. Secara khusus, kostumer sekolah adalah siswa dan keluarganya. Merekalah yang memetik manfaat dari sekolah. Para orang tua merupakan pemasok sistem pendidikan. Orang tua menyerahkan anaknya kepada sekolah bermutu terpadu sebagai siswa yang siap belajar. Tanggung jawab sekolah bermutu terpadu untuk bekerja bersama para orang tua mengoptimalkan potensi siswa agar mendapat manfaat dari proses belajar di sekolah. Sekolah memiliki kostumer internal dan eksternal. Kostumer internal adalah orang tua, siswa, guru, administrator, staf dan dewan sekolah yang berada dalam sistem pendidikan. Kostumer eksternal adalah masyarakat, perusahaan, keluarga, militer dan perguruan tinggi yang berada di luar organisasi, namun memanfaatkan output proses pendidikan. Sebuah relasi terbangun antara harapan kostumer pada Anda dan apa yang Anda harapkan dari pemasok.

Keterlibatan Total. Setiap orang harus berpartisipasi dalam transformasi mutu. Mutu bukan hanya tanggung jawab dewan sekolah atau pengawas, tetapi tanggung jawab semua pihak. Mutu menuntut setiap orang memberi kontribusi bagi upaya mutu.

Pengukuran. Anda tidak dapat memperbaiki apa yang tidak dapat Anda ukur. Sekolah tidak dapat memenuhi standar mutu yang ditetapkan masyarakat, sekalipun ada sarana untuk mengukur kemajuan berdasarkan pencapaian standar tersebut. Para siswa menggunakan nilai ujian untuk mengukur kemajuannya di kelas. 
Komitmen. Para pengawas sekolah dan dewan sekolah harus memiliki komitmen pada mutu. Bila mereka tidak memiliki komitmen, proses formasi mutu tidak akan dapat dimulai karena kalaupun dijalankan pasti gagal.

Perbaikan Berkelanjutan. Para profesional pendidikan harus secara terus menerus menemukan cara untuk menangani masalah yang muncul, mereka harus memperbaiki proses yang dikembangkannya dan membuat perbaikan yang diperlukan.

Untuk menjalankan manajemen mutu terpadu membutuhkan manajer yang mampu mengesampingkan sejenak keuntungan jangka pendek dan menetapkan tujuan keberhasilan jangka panjang. Menurut Sallis (2012) untuk tetap terdepan dalam kompetisi, sebuah oranisasi harus mengetahui kebutuhan pelanggan, kemudia menyatukan pikiran untuk bertindak memenuhi kebutuhan mereka.

\section{Penjaminan Mutu Melalui Model PDCA dalam Proses Manajemen Mutu Terpadu Pendidikan}

Pelaksanaan penjaminan mutu pendidikan terutama berada pada satuan/program pendidikan. Penyelenggaraan satuan/program pendidikan berkewajiban menyediakan dan memberikan bantuan dalam pemenuhan standar (Nanang Fattah, 2013). Agar lembaga pendidikan islam eksistensinya terjamin, maka harus menjalankan proses penjaminan mutu pendidikan yang diselenggarakannya. Mengingat karena penilaian stakeholders senantiasa berkembang, maka penjaminan mutu juga harus selalu disesuaikan pada perkembangan itu secara berkelanjutan. Pasal 91 UU Sisdiknas Tahun 2005, berbunyi: “(1) Setiap satuan pendidikan pada jalur formal dan non formal wajib melakukan penjaminan mutu pendidikan; (2) Penjaminan mutu pendidikan sebagaimana dimaksud pada ayat (1) bertujuan untuk memenuhi atau melampaui standar nasional pendidikan. (3) Penjaminan mutu pendidikan sebagaimana dimaksud pada ayat (1) dilakukan secara bertahap, sistematis, dan terencana dalam suatu program penjaminan mutu yang memiliki target dan kerangka waktu yang jelas". 
Secara umum yang dimaksud dengan penjaminan mutu adalah proses penetapan dan pemenuhan standar mutu pengelolaan secara konsisten dan berkelanjutan, sehingga konsumen, produsen, dan pihak lain yang berkepentingan memperoleh kepuasan (Depdiknas, 2003). Upaya peningkatan mutu secara terus menerus harus dilakukan dengan harapan akan menumbuhkan budaya mutu sehingga akan tercapai peningkatan standar yang berkelanjutan.

Menurut Snyder dkk. dalam Syarafuddin (2002), system manajemen mutu dirancang untuk memenuhi mutu terpadu. Standar system mutu menentukan ukuran pengawasan yang diperlukan untuk memastikan bahwa produk jadi atau jasa sesuai dengan kebutuhan pelanggan. Mutu menjadi hal yang sangat sentral dalam manajemen mutu terpadu. Guna mengendalikan dan menjamin mutu tersebut, manajemen mutu terpadu bertujuan untuk memberikan kepastian bahwa setiap kegiatan memberikan kontribusi guna mencapai tujuan utama bisnis dan dilaksanakan dengan penuh efisiensi. Falsafah dasar mutu terpadu adalah mengerjakan pekerjaan benar dengan tepat sejak pertama kali. Berkaitan dengan perbaikan mutu dijelaskan oleh Deming sebagai proses yang tidak pernah berhenti. Konsepnya terkenal dengan PDCA (Plan, Do, Check, dan Action), yaitu rencanakan, laksanakan, pantau, dan lakukan perbaikan. Model PDCA memuat 4 (empat) langkah proses kendali mutu yang meliputi: perencanaan/plan (apa saja yang akan dikerjakan? serta bagaimana mengerjakannya?; (2) pelaksanaan/do (lakukan apa yang sudah direncanakan); (3) evaluasi/check (apakah sesuatu yang dilakukan sudah berjalan sesuai dengan rencana?), dan (4) tindakan penyempurnaan/action (tahapan melaksanakan tindakan untuk proses pengembangan berkelanjutan atau kaizen).

Dalam tahapan tersebut, kendali mutu termasuk pada tahapan ketiga yaitu check yang berfungsi untuk melihat keadaan saat ini guna dibandingkan dengan kadaan yang diharapkan. Jika antara kedua kondisi tersebut terdapat kesenjangan, maka perlu dilakukan koreksi pelaksanaan program, direncanakan kembali langkahlangkahnya, dan dikerjakan langkah-langkah yang telah 
direncanakan tersebut. Dalam proses penjaminan mutu, model PDCA digunakan sebagai pengendalian kualitas penjaminan mutu yang pada prinsipnya seluruh unit kerja di lingkungan lembaga pendidikan harus melandasi pola pikir dan pola tindak dengan memprioritaskan mutu yang bertujuan memberikan kepuasan costumer. Oleh karena itu menurut Nana Fattah (2013) penjaminan mutu pendidikan menjadi tanggung jawab bersama dari berbagai pihak. Tahapan penjaminan mutu pendidikan dimulai dari penetapan standar mutu, pemenuhan standar, pengukuran dan evaluasi dengan cara pengumpulan data dan analisis, perbaikan dan pengembangan standar dalam peningkatan mutu pendidikan yang mengacu pada acuan mutu pendidikan, yakni standar pelayanan minimal, standar nasional pendidikan, dan standar mutu pendidikan yang melampaui standar nasional pendidikan.

\section{Catatan Akhir}

Dalam tataran konsep maupun implementasi, manajemen mutu terpadu sangat bermanfaat terhadap dunia pendidikan islam. Mutu terpadu pendidikan dipahami sebagai suatu proses yang melibatkan pemusatan pada pencapaian kepuasan harapan pelanggan pendidikan, perbaikan terus menerus, pembagian tanggung jawab dengan para staf, dan pengurangan pekerjan tersisa dan pengerjaan kembali. Manajemen Mutu Terpadu menawarkan solusi baru tentang perbaikan mutu pendidikan islam. Upaya peningkatan mutu secara terus menerus harus dilakukan dengan harapan akan menumbuhkan budaya mutu sehingga akan tercapai peningkatan standar yang berkelanjutan. Untuk memperbaiki mutu lembaga pendidikan islam diperlukan keterlibatan semua pihak. Penerapan mutu terpadu secara benar akan menjamin bahwa para pemimpin lembaga pendidikan islam dapat mengendalikan usahanya. Dalam kaitan ini peran dan fungsi sistem penjaminan mutu sangat dibutuhkan. Kegiatan penjaminan mutu diarahkan pada proses untuk membangun kepercayaan dengan cara melakukan pemenuhan standar minimum, baik pada komponen input, proses, maupun output. 


\section{Daftar Pustaka}

Arcaro, Jerome S. 2005. Pendidikan Berbasis Mutu. Yogyakarta: Pustaka Pelajar.

Dedi Hamid. 2003. Undang-undang Sistem Pendidikan Nasional, No 20 Tahun 2003. Jakarta: Asokadikta dan Durat Bahagia.

Fandy Tjiptono dan Anastasia Diana. 1995. TQM: Total Quality Management. Yogyakarta: ANDI Offset.

Furqon dan Burhanuddin Tola (2002). Pengembangan Model Penilaian Sekolah Efektif. http://www.depdiknas.go.id/Jurnal/44

http:/ / gurupembaharu.com/home/manajemen-perubahanantipasi-penerapan-kurikulum-2013/

Mujamil Qomar. 2002. Manajemen Pendidikan Islam. Jakarta: Erlangga.

Nanang Fattah. 2013. Sistem Penjaminan Mutu Pendidikan. Bandung: Rosdakarya.

Pupuh Fathurrohman dan AA Suryana. 2011. Supervisi Pendidikan. Bandung: Refika Aditama.

Ramayulis. 2002. Ilmu Pendidikan Islam. Jakarta: Kalam Mulia.

Robert Mirsel. 2004. Teori Pergerakan Sosial, Kilas Sejarah, dan Catatan Bibliografis. Yogyakarta: Resist Book.

Sallis, Edward. 2003. Total Quality Management in Education. London:

Kogan Page Educational Management Series. - 2012. Manajemen Mutu Terpadu Pendidikan, Peran Strategis Pendidikan di Era Globalisasi Modern. Yogyakarta: Ircisod.

M. Sobry Sutikno. 2007. Pengelolaan Pendidikan (Tinjauan Umum dan Islami). Bandung: Prospect.

Nana Syaodih Sukmadinata, Ayi Novia Jami’at dan Ahman (2006)

Pengendalian Mutu Pedidikan Sekolah Menengah (Konsep, Prinsip, dan Instrumen). Bandung: Refika Aditama.

Nana Syaodih Sukmadinata, Ayi Novia Jami'at dan Ahman. 2003. Pengendalian Mutu Pendidikan Sekolah Dasar: Konsep, Prinsip dan Instrumen. Bandung: Kesuma Karya.

Syafaruddin. 2002. Manajemen Mutu Terpadu dalam Pendidikan (Konsep, Strategi, dan Aplikasi). Jakarta: Grasindo. 